\title{
Multinational Measles Outbreak in Post-Elimination Era, Involves Three Countries of North America and a European Country in a Short Transmission Chain
}

\author{
Cuitláhuac Ruiz-Matus', Lorena Suárez-Idueta1, Ilse Herbas-Rocha², José Luis Diaz-Ortega3*, \\ Edith Cruz-Ramírez", Abraham Ramírez-Jurado5, Irma López-Martínez ${ }^{4}$, José Cruz \\ Rodríguez-Martínez ${ }^{1}$, José Alberto Díaz-Quiñonez ${ }^{4}$ \\ ${ }^{1}$ General Directorate of Epidemiology, Ministry of Health, Mexico City, Mexico, \\ ${ }^{2}$ National Center for Health of Children and Adolescents, Ministry of Health, Mexico City, Mexico \\ ${ }^{3}$ National Institute of Public Health, Mexico City, Mexico \\ ${ }^{4}$ Institute for Epidemiological Diagnosis and Reference, Ministry of Health Mexico, Mexico City, Mexico \\ ${ }^{5}$ State Health Services, Quintana Roo, Mexico \\ Email: jdiaz@insp.mx
}

Received 25 February 2015; accepted 11 April 2015; published 16 April 2015

Copyright (C) 2015 by authors and Scientific Research Publishing Inc.

This work is licensed under the Creative Commons Attribution International License (CC BY). http://creativecommons.org/licenses/by/4.0/

c) (i) Open Access

\section{Abstract}

Background: Four measles cases in Canada and one in the United States are linked to international importation of measles in Playa del Carmen, Quintana Roo, Mexico. Objective: To describe characteristics of transmission and not spillover to local population in Mexico. Material and Methods: The outbreak investigation was based on active search of cases and in the rapid monitoring of vaccination coverage in children aged 1 - 7 years old. Laboratory confirmation by Enzyme-Linked Immunosorbent Assay (ELISA) and molecular detection by Reverse Transcriptase-Polymerase Chain Reaction (RT-PCR) assay in throat swab and urine were done. Results: One transmission chain with three generations of cases was identified. The primary case was a 9-year-old boy who was infected in Wales, UK. His sisters aged 7 and 15 years old respectively, were the first generation of cases in Mexico. The second generation was related to the imported cases, and affected two Canadian tourists and an American woman aged 39 years old. A third generation occurred in Canada and affected an infant of 15 months of age and his sister aged 4 years old. The genotype D8 which was circulating in UK was identified in these patients. One probable case was detected in Quintana Roo, but was discarded by laboratory testing. The coverage with at least one dose of Measles-Mumps-Rubella (MMR) vaccine ranged from $\mathbf{9 5 \%}$ to $\mathbf{9 9 . 5 \%}$. Conclusion: International

\footnotetext{
"Corresponding author.
}

How to cite this paper: Ruiz-Matus, C., et al. (2015) Multinational Measles Outbreak in Post-Elimination Era, Involves Three Countries of North America and a European Country in a Short Transmission Chain. World Journal of Vaccines, 5, $79-87$. 
travelers with no history of vaccination are at risk of acquiring measles even in countries that have interrupted endemic transmission. The high immunization coverage of measles containing vaccine could explain the absence of cases in Mexican population. Highlights: Multinational measles outbreak in a country without endemic transmission. The findings exhibit the importance of immunization in international travelers in the post-elimination era.

\section{Keywords}

\section{Measles Multinational Outbreak, Transmission in Post-Elimination Era, Genotype D8}

\section{Introduction}

Measles is a significant cause of mortality in children under 5 years of age in developing countries. In the period 2000-2011, the worldwide incidence diminished from 146 to 52 cases per million inhabitants (65\% reduction), and deaths from 548,000 to 158,000 (71\% reduction) [1] [2]. Measles vaccine was introduced in Mexico in 1972, in 1991 a schedule of two doses of vaccine was adopted, the first one applied at 12 months of age and the second at 6 years old. In 1997 the MMR replaced this vaccine [3]-[5].

Mexico have carried out regional strategies for measles elimination [6], a catch-up immunization campaign in 1993, addressed to children from 9 months old to 14 years old (85.4\% coverage), and periodic follow-up campaigns, irrespective of the history of MMR vaccination in 1 - 4 year-old children in 1998, 2002, and 2010-2011 (90.5\%, 91.8\%, and 98.5\% coverage respectively). Different immunization strategies with MR vaccine have been performed in adolescents and adults up to 39 years of age since 2000. An immunization campaign for adults aged 19 - 29 years old was performed in 2008 (92.5\% coverage). In 2010, 87.47\% of 2445 municipalities fulfilled the regional indicator of at least $95 \%$ of vaccination coverage in 1-year-old children [7] [8].

The last endemic case occurred in Mexico in 1995 [4] [5] [7] [8], and in 2002 in the Americas [6]; however, some imported cases from Africa, Southeast Asia and Europe continue to occur in the continent [6] [7]. Due to insufficient population immunity in some countries [9]-[12], there have been frequent outbreaks of measles in European region since 2008 [13]-[24], some have generated secondary cases in the Americas, mainly in Canada, United States, Brazil, Ecuador and Mexico [6] [25]-[28].

On epidemiological week 8 of 2013, the International Health Regulations (IHR) reported the occurrence of 2 measles cases in United Kingdom; on week 9, IHR notified 3 confirmed cases and 2 probable ones in Canada. The Pan American Health Organization reported 1 further case in the United States (week 10). Six cases had travelled for vacations to Playa del Carmen in the municipality "Solidaridad" of state Quintana Roo [29]-[31]. In order to analyze the spreading of transmission and procedures carried out for the outbreak control, we developed the field investigation that was described below.

\section{Material and Methods}

\subsection{Population}

Outbreak investigation and rapid monitoring of vaccination coverage were performed in Solidaridad, and in three municipalities that surround it: Benito Juárez (Cancun), Tulum and Isla Mujeres which receive most of national and international tourists.

\subsection{Operational Case Definition [6] [32]}

Suspected (SC): Person of any age with a fever and maculopapular rash.

Probable (PC): SC with one or more signs: cough, coryza, conjunctivitis.

Confirmed: PC confirmed by laboratory or by epidemiological link to another confirmed case by laboratory.

\subsection{Active Search}

A network of daily reporting by email of suspected cases was established in 222 health units of first and second care level in the 10 municipalities of the state and at Cancun International Airport. Health workers were trained 
in detection, reporting, and laboratory sampling of probable cases. Also we carried out daily report of non attendance to job in the hotel staff, and monitor job absences in other 4 hotels related with the findings of community search in Cancun, Tulum and Playa del Carmen. Workers were interviewed to evaluate the cause and presence of possible symptoms compatible with measles, including their contacts. Active search of suspected cases was performed in houses surrounding the hotel (49 block radius) [32].

We used a structured questionnaire for interviews, which included questions of nationality, age, sex, type of relationship with cases, history of measles and of immunization, and current symptoms if any. We collected laboratory samples from individuals who met the PC definition.

\subsection{Vaccination Coverage}

Rapid monitoring of vaccination coverage was carried out by method of lot quality assurance sampling, with precision level of 5\% and confidence level of 95\%. The primary sampling-units were lots of basic geostatistical areas (AGEB). A sample size of 422 children for each municipality was proportionally distributed to population size of each lot selected. On a map, we identified the block located in the center of each AGEB, the blocks surrounding it were numbered in the sense of clockwise, houses inside each block were numbered in the same way. In rural areas numbering began with the house located in northeastern section, and continued south, then to east and upwards north and so on. Dwellings were randomly selected [33] [34].

Field workers were trained on interview methods and application pre-coded questionnaire, containing sociodemographic information and on doses applied of vaccine. If a house was closed during three visits, or when the responsible of a child, did not accept participation, interviewers visited the home next door to the right, to get information of a child of 1 - 5, and/or 6 - 7 years of age. Only doses registered in an official document were validated as applied.

\subsection{Outbreak Response}

Geographic areas surrounding the hotel, and the 4 municipalities described previously, were considered areas on risk for transmission. The MR vaccine was offered to all 220 employees. Also we urged parents of children and adolescents by radio, local press and by promotion activities in neighborhoods and clinics, to check their immunization status, and if not up-to-date or if unknown, to attend a health center of the locality to receive free the MMR vaccine.

\subsection{Laboratory Methods}

Cases were confirmed in the countries of origin, the genotyping results were informed by the IHR and the Centers for Disease Control and Prevention of the United States. Samples of blood, throat swab and urine were collected from a probable case in Tulum. The serum sample was processed in the Laboratory of Public Health (LPH) in Quintana Roo by ELISA-IgM against measles and by ELISA-IgM for rubella, if result for measles was negative. Samples of urine and throat swab were sent to the National Reference Laboratory (Instituto de Diagnóstico y ReferenciaEpidemiológicos, InDRE, Mexico City, Mexico) for viral detection by RT-qPCR, as described [35]. InDRE also carried out quality control for serological results of LPH of Quintana Roo, according to international standard procedures [36].

\subsection{Data Analysis}

In order to identify transmission chains, and generations of secondary cases we considered the dates of arrival and departure of Mexico and of rash onset, considering an incubation period of 21 days, and a transmissibility period of 4 days before and 4 days after the rash onset. Questionnaires of the rapid monitoring of immunization coverage were reviewed and validated by supervisors, before to be entered into a spreadsheet. We estimated the percentage of children with measles vaccination and its respective $95 \%$ confidence intervals for one and two doses of measles vaccine per lots analyzed by municipality.

\section{Results}

In the period 2000-2012, administrative coverage for MMR vaccine in Mexico ranged from $95.2 \%$ to $98.8 \%$. 
Since 2003, Mexico documents a reporting rate of suspected cases, equal or greater 2 per 100,000 inhabitants, and fulfills in over $80 \%$ indicators of opportune investigation of cases and outbreaks, with adequate specimens, its timely shipment to laboratory, with timely laboratory results [7] [37].

\subsection{Characteristics of Cases}

The index cases in Mexico were a 7-year-old girl and her sister of 15 years of age, both arrived from UK with their family to Cancun airport on February 2 of 2013. The secondary cases epidemiologically related to the index cases were a man of New Brunswick, and a woman of Ontario, both Canadians of 39 years of age who were not related each other, and a woman of 39 years of age of the state of Florida, United States. The Canadian man travelled to Mexico with his son of 15 months of age. The Canadian and North American tourists spent the exposure period of infection in the same hotel of Playa del Carmen where the index cases were hosted. With exemption the index cases who started rash on the same day of their exit of Mexico, none of the secondary cases initiated clinical manifestations in Mexico. During development of field investigation, Canada reported the incidence of two new cases linked to Playa del Carmen outbreak, in the province of New Brunswick (Can-3 and Can-4). The history of measles immunization was unknown in one case; in the rest of patients the vaccination history was negative. All cases fulfilled the clinical definition of confirmed measles (see Material and Methods). None of the cases were hospitalized or died.

\subsection{Active Search of Cases}

Figure 1 shows the continuous report of probable cases by epidemiological week. The indicator of at least 2 probable cases per 100,000 inhabitants was fulfilled in the period 2008-2013 at national level, as can see in the annual incidence curve. In Quintana Roo, this indicator was in limits of fulfillment in 2012 (1.9 per 100,000 inhabitants). The daily negative network of Quintana Roo, reported four suspected cases in Cancun and one probable case in Tulum. The four suspected cases did not meet definition of probable case. The probable case was a female infant of 7 months of age without history of immunization, who was discarded of measles and rubella by serology and by PCR. Samples of serum, throat swab and urine, were collected three days after the rash onset. The father of probable case was a guard at a hotel in Tulum, which remained asymptomatic. In the period pending the results of laboratory, and taking into account the possibility that this were an asymptomatic rubella infection, monitoring of absences from work, spread to this hotel and three others with frequent exchange of personnel with this hotel. There were not suspected or probable cases, of measles/rubella, in the five hotels under surveillance. The active and retrospective search in community (current cases and those occurred in the last 5 weeks) performed from 6 to March 8 did not detect additional suspected cases or probable ones.
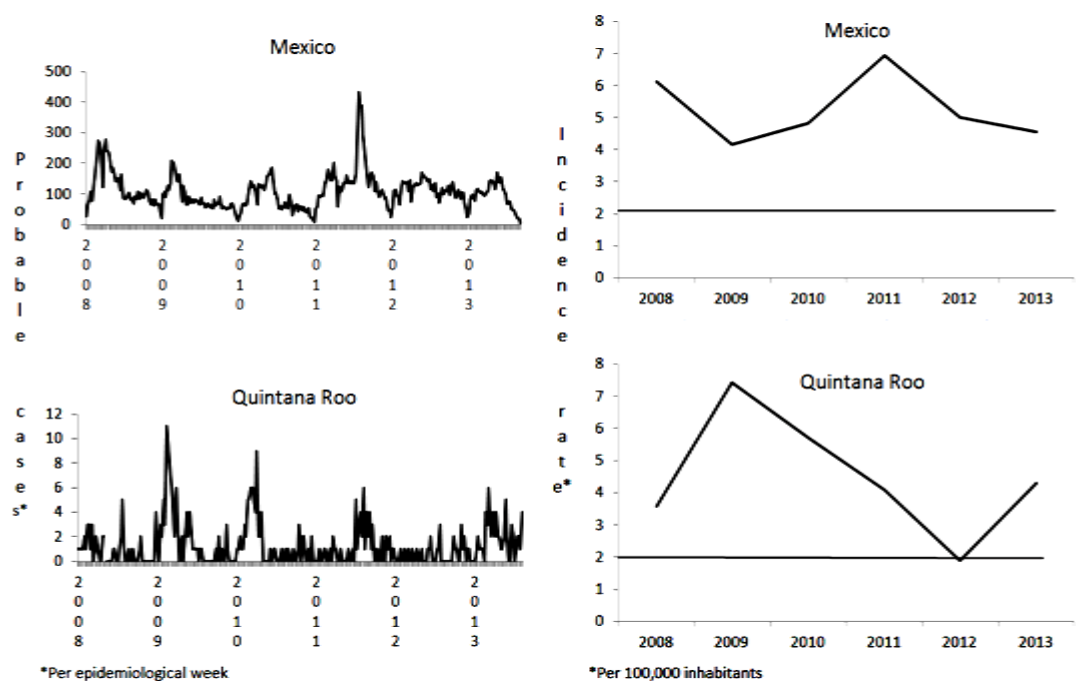

Figure 1. Probable cases of measles per epidemiological week and annual incidence in Mexico and Quintana Roo, 2008-2013. 


\subsection{Transmission Chain}

\subsubsection{Primary Case and First Generation of Secondary Cases}

The transmission chain started in Wales, UK the primary case was a non-immunized boy of 9 years of age (UK-1), who was infected at school, and started rash on February 5th. The boy transmitted the infection, to his sisters of 7 (UK-2) and 15 years (UK-3) of age, during his pre-rash transmissibility period. Both patients traveled to Mexico in incubation period, in a direct flight from Birmingham, UK, reaching the international airport of Cancun, Quintana Roo, on February 2 of 2013. They moved from the airport to Playa del Carmen (67 Km from Cancun) by road transportation. On February 14, they started prodromal manifestations, with onset of rash on February 16, last day of their stay in the country (Figure 2). Both cases had no history of measles immunization.

\subsubsection{Second Generation of Secondary Cases}

Considering the date onset of rash of the index cases, their transmissibility period probably occurred between February 11 and 20. During such a period, three Canadian tourists hosted in the same hotel where cases UK-2 and UK-3 were hosted: A man of 39 years of age (Can-1) and his son of 15 months of age were staying at the hotel between February 5 and 12, the father started rash on February 19. In addition, a woman aged 39 years (Can-2), hosted in the hotel between February 9 and 16, presented rash on March 1st. The exposure period of both cases overlapped with the transmissibility period of cases UK-2 and UK-3. In addition, the exposure period of the case Can-2 overlapped with the transmissibility period of the case Can-1 (Figure 2).

A 39-year-old woman from the United States (US-1), also hosted at the hotel between 7 and 12 February, started rash on February 19, her exposure period overlapped with the transmissibility period of the cases UK-2, UK-3 (Figure 2). The measles immunization history was negative in the three Canadian cases and ignored in the US case. The three secondary infections in adults were considered as imported cases from Mexico in Canada and USA.

\subsubsection{Third Generation of Secondary Cases}

Canadian Health Authorities considered that cases Can-3, and Can-4 were acquired locally in New Brunswick, although the exposure period of case Can-3, the infant of 15 months of age who spent vacations with his father (Can-1) in Playa del Carmen, overlapped with the transmissibility period of the cases UK-2, UK-3, US-1 and Can1 , this case only had direct and continuing contact with case Can-1. The case Can- 4 , a girl of 4 years of age, acquired measles locally, and infection could have been transmitted by cases Can-1 or Can-3. None of the two cases had history of immunization (Figure 2). None of the cases had clinical complications, nor was hospitalized.

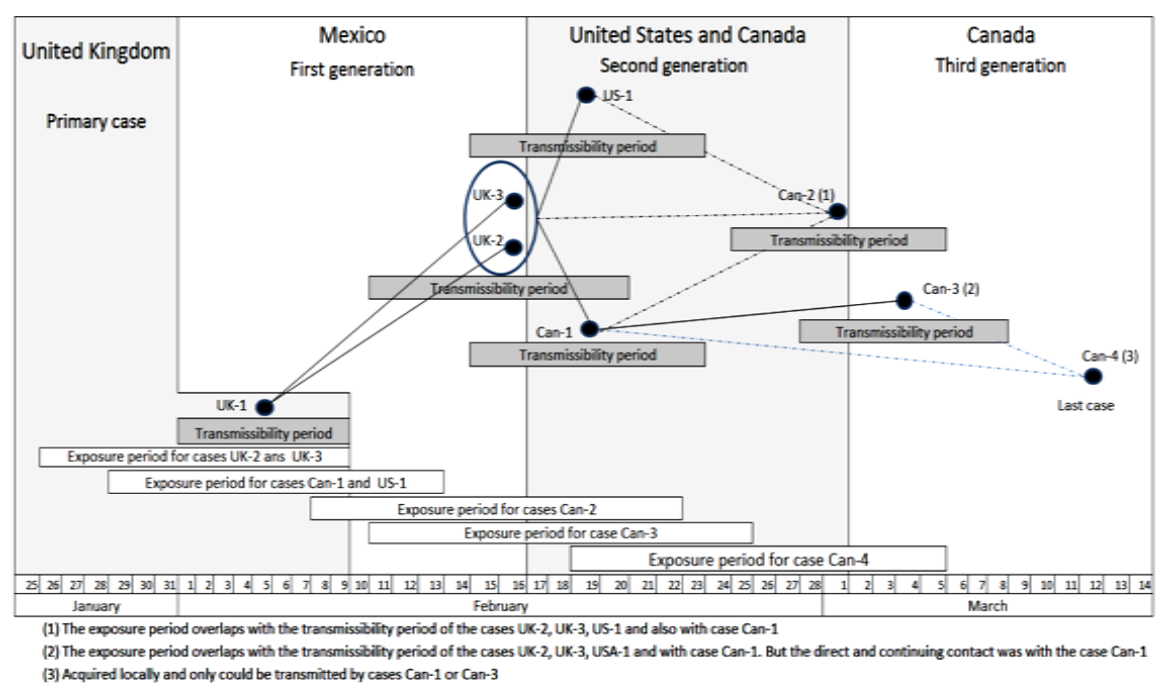

Figure 2. Transmission chain and generations of secondary measles cases: United Kingdom, Mexico, United States and Canada. Source: International Health Regulations, Pan American Health Organization, Directorate of General Epidemiology. 
Genotype D8 was identified in the three generations of secondary cases.

\subsection{Transmission Risk to Other Passengers and Crew}

Considering that index cases, arrived to Mexico on February 2nd, and that the period of transmissibility began approximately on February 11, there was no risk of transmission to passengers or the crew of the direct flight from UK to Cancun. In contrary, in the return travel to UK, both patients were in period of transmissibility, and potentially could have transmitted measles to other passengers and to crew, if they were susceptible. On the other hand, taking into account, the date of departure of Mexico and parameters of transmissibility (Figure 2), there was not risk of transmission in the return flights of the Canadian or American tourists.

\subsection{Rapid Monitoring of Vaccination Coverage}

We contacted 1774 children; 1353 (76\%) had 1 - 5 years of age, and 421 (24\%) had 6 - 7 years of age.

\subsubsection{Coverage with 1 Dose of MMR Vaccine}

Children aged 1 - 5 years. Only parents of 1164 (86\%) children were able to present their immunization card, coverage ranged from 97.3\% (95\% CI: 95 - 100) in Isla Mujeres to 97.6\% (95\% CI: 97\% - 100\%) in Benito Juárez (Figure 3).

Children aged 6 - 7 years old. Figures correspond to 351 children (83\%) with immunization card. The coverage ranged from 95.0\% (95\% CI: 91-100) in Tulum to 99.5\% (95\% CI: 99 - 100) in Benito Juarez and Isla Mujeres (Figure 3).

\subsubsection{Coverage with 2 Doses of MMR/MR Vaccine in Children of 6 - 7 Years of Age}

Coverage ranged from 65.1\% (95\% CI: 55\% - 75\%) in Tulum to 93.4\% (95\% CI: 86\% - 100\%) in Isla Mujeres (Figure 3).

\subsection{Outbreak Response}

Although health services had carried out immunization activities in personnel of that and other hotels in previous years, voluntary vaccination, irrespective of immunization history, was performed in $79 \%$ of the staff. Most of employees, who rejected vaccination, did not have contact with guests. In total 325 doses of MR or MMR were applied in control activities in the five hotels and in the community.
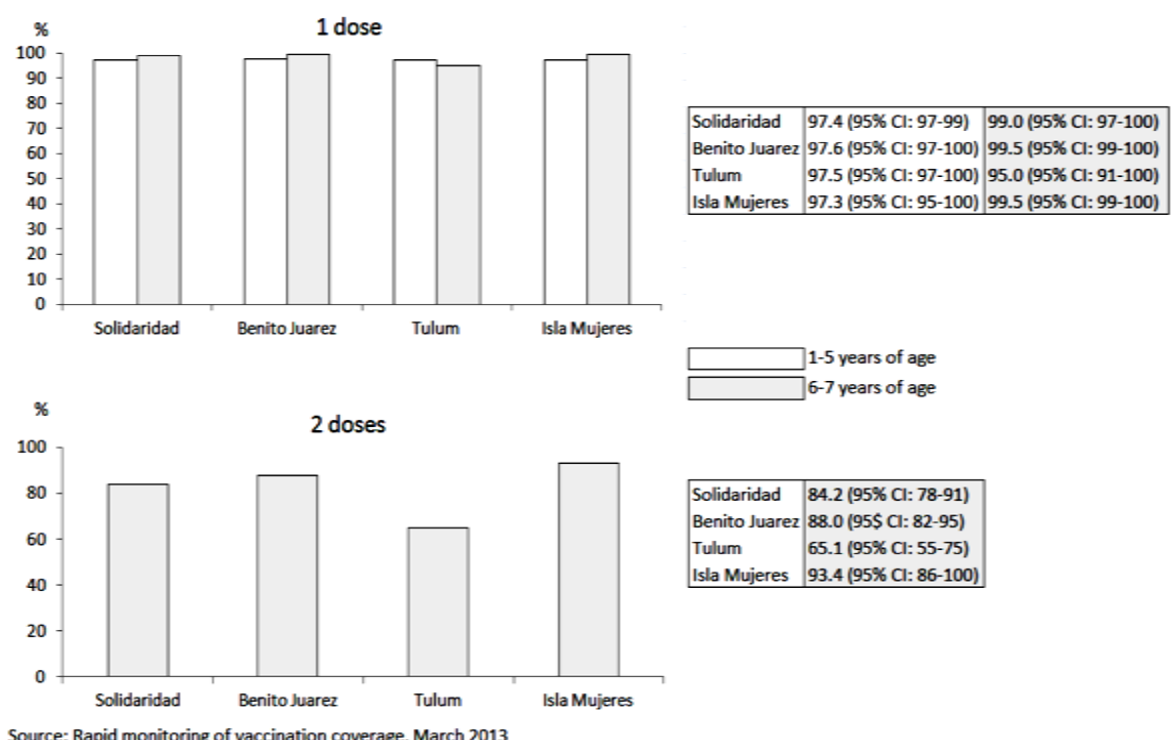

Benito Juarez 88.0 (95\$ Cl: $82-95$ )

\begin{tabular}{l|ll} 
Tulum & $65.1(95 \%$ C: $55-75)$ \\
\hline
\end{tabular}

Isla Mujeres 93.4 (95\% Cl: 86-100)

Figure 3. Immunization coverage with 1 or 2 doses of measles containing vaccine in children of 1 - 5 years of age, and 6 - 7 years of age, according to rapid monitoring of vaccination coverage. 


\section{Discussion}

Reemergence of measles in European countries [13]-[24] highlighted the importance of maintaining proper coordination with the IHR. The outbreak involved four countries and included three generations of secondary cases, Mexico was a kind of "test tube" where the contact between infected patients of UK and susceptible individuals was given, which affected only some tourists from Canada and the United States.

Epidemiological surveillance in Mexico had sensitivity enough to detect importations and capacity to shoot timely outbreak response by the immunization program. Although administrative immunization coverage was higher than 95\% in the period 2000-2012, these data likely could explain the absence of measles cases in the Mexican population during this outbreak, however, results of the National Nutrition and Health Survey conducted in late 2011 and early 2012 found that coverage in children of 15 - 23 months of age was of $87.6 \%$ (95\% CI 83.7, 89.8), and coverage in the same age group in Quintana Roo was 90.3\% (95\% CI 75.3, 96.6). According to this survey, the coverage for 1 dose of MMR vaccine in children aged 6 years old was $93.2 \%$ (95\% CI 91.3, 95.0), but was only of 56.5\% (95\% CI 52.5\%, 60.5\%) for 2 doses [38].

On the other hand, results of the rapid monitoring of vaccination coverage showed figures above 95\% with 1 dose of MMR vaccine, while for 2 doses, coverage was low and unacceptable in the town of Tulum. Considering that was not possible to document the application of the second dose of vaccine in a significant proportion of children in Tulum, findings suggest that the persistence of immunity attributable to the first dose, could explain the absence of measles cases in Mexico during this multinational outbreak.

In the multinational outbreak emerged complex scenarios for classification an ailment now eliminated in the Americas, index cases were classified as imported from UK in Mexico, while the cases of Canada and the United States were classified as imported from Mexico [30] [31], which was confusing considering that Mexico only provided space for contact between infected and susceptible individuals and not contributed with own cases to the chain of measles transmission. Some authors have found that non-immune international travelers present a great risk of getting measles when they travel not only to endemic countries, but also when they go to those countries where the transmission of this illness has been eliminated [39]. In an outbreak occurred aboard of a cruise that disembarked in Italy to ask for medical attendance for 27 suspected cases of measles of different nationalities, the event was classified as "a cross-border health threat" [40].

Among limitations of the study should be highlighted we could not identify the total of individuals who had contact with the index cases, and the second generation of cases, however, results of active search including those reports of the network daily report, suggested that there were no more cases linked with this outbreak. On the other hand, due to the immunization schedule, embraces between 15 and 17 doses of 6 to 7 vaccines (26 antigens) in children of these age groups, only those who had immunization card were included in the rapid monitoring of vaccination coverage.

We recommended Mexican health authorities to improve distribution of vaccination card and strengthen staff training in the registration of vaccine doses. Health services should monitor vaccination coverage with 1 and 2 doses of MMR to establish corrective interventions locally, and recommend international travelers to update their immunization schedule for measles if any before departing.

\section{Conclusion}

International travelers are at risk of acquiring measles, even in those countries that have interrupted endemic transmission; this outbreak underlies the importance of immunization in those travelers during the post elimination era. The high immunization coverage of measles containing vaccine could explain the absence of cases in Mexican population.

\section{Acknowledgements}

Thanks all federal, state and local health workers who worked on the field investigation.

\section{References}

[1] Wolfson, L.J., Strebel, P.M., Gacic-Dobo, M., Hoekstra, E.J., McFarland, J.W. and Hersh, B.S. (2007) Has the 2005 Measles Mortality Reduction Global Been Achieved? A Natural History Modelling Study. The Lancet, 369,191-200. http://dx.doi.org/10.1016/S0140-6736(07)60107-X 
[2] Perry, R.T., Gacic-Dobo, M., Dabbagh, A., Strebel, P.M., Okwo-Bele, J.M. and Goodson, J.I. (2013) Global Control and Regional Elimination of Measles, 2000-2011. Morbidity and Mortality Weekly Report, 62, $27-31$.

[3] Velázquez-Monroy, O.J., Alavarez-Lucas, C.H., Lezana-Fernández, M.A. and Avila-Figueroa, C. (1990) Panorama epidemiológico del sarampión en México: Situación actual y perspectivas. Boletín Médico del Hospital Infantil de México, 47, 462-473.

[4] Díaz-Ortega, J.L. and Montesano-Castellano, R. (1998) Rompiendo la cadena: Eliminación del sarampión en México. In: Santos Preciado, J.I., Ed., Infectología, Interamericana-Mc-Graw-Hill, México, D.F., 258-272.

[5] Herbas Rocha, I.M.J. and Villanueva-Domínguez, J. (2010) Vacunación y panorama epidemiológico del sarampión en México 1989-2009. Revista de Enfermedades Infecciosas en Pediatría, 23, 36.

[6] OPS (2011) Plan de acción para la documentación y verificación de la eliminación de sarampión, rubéola y síndrome de rubéola congénita en la Región de las Américas. Organización Panamericana de la Salud, Washington DC.

[7] Comisión Nacional para la Documentación y Verificación de la Eliminación del Sarampión, Rubéola y Síndrome de Rubéola Congénita en México. Informe Final. Febrero de 2012.

[8] Díaz Ortega, J.L. (2013) Las estrategias de eliminación regional en la re-emergencia global del sarampión. Sensor. Boletín electrónico de Sociedad, género y políticas públicas. Información para el desarrollo del estado de Oaxaca, 12, 22-25.

[9] Martin, R., Deshevoi, S., Buddha, N. and Jankovic, D. (2009) Approaching Measles and Rubella Elimination in the European Region-Need to Sustain the Gains. Eurosurveillance, 14, pii=19449. http://www.eurosurveillance.org/ViewArticle.aspx?ArticleId=19449

[10] WHO (2013) Progress in Global Control and Regional Elimination of Measles, 2000-2011. The Weekly Epidemiological Record, 88, 29-36.

[11] Andrews, N., Tischer, A., Siedler, A., Pebody, R.G., Barbara, C., Cotter, S., Duks, A., Gacheva, N., Bohumir, K., Johansen, K., Mossong, J., de Ory, F., Prosenc, K., Sláčiková, M., Theeten, H., Zarvou, M., Pistol, A., Bartha, K., Cohen, D., Backhouse, J., Griskeviciuss, A. and Nardonea, A. (2008) Towards Elimination: Measles Susceptibility in Australia and 17 European Countries. Bulletin of the World Health Organization, 86, 197-204. http://dx.doi.org/10.2471/BLT.07.041129

[12] Dobson, R. (2008) England and Wales Are among Countries at Risk of Measles Epidemic. BMJ, 336, 66. http://dx.doi.org/10.1136/bmj.39451.636146.DB

[13] Ghebrehewet, S., Hayhurst, G., Keenan, A. and Moore, H. (2012) Outbreak of Measles in Central and Eastern Cheshire, UK, October 2008-February 2009. Epidemiology and Infection, 9, 1849-1856. http://dx.doi.org/10.1017/S0950268812002300

[14] Limb, M. (2012) Outbreaks among Travellers Linked to almost Two Fold Rise in Measles Cases. BMJ, 345 , e5797. http://dx.doi.org/10.1136/bmj.e5797

[15] Wise, J. (2013) Measles Outbreak Hits Northeast England. BMJ, 346, f662. http://dx.doi.org/10.1136/bmj.f662

[16] Wise, J. (2013) Largest Group of Children Affected by Measles Outbreak in Wales Is 10-18 Year Olds. BMJ, 346, f2545. http://dx.doi.org/10.1136/bmj.f2545

[17] Huoi, C., Casalegno, J.S., Benet, T., Neuraz, A., Billaud, G., Eibach, D., Mekki, Y., Rudigoz, R., Massardier, J., Huissoud, C., Massoud, M., Gaucherand, P., Claris, O., Gillet, Y., Floret, D., Lina, B. and Vanhems, P. (2012) A Report on the Large Measles Outbreak in Lyon, France, 2010 to 2011. Eurosurveillance, 17, pii=20264. http://www.eurosurveillance.org/ViewArticle.aspx?ArticleId=20264

[18] Mortamet, G., Dina, J., Freymuth, F., Guillois, B. and Vabret, A. (2012) Rougeole: que retenir de l'année 2011? Archives de Pédiatrie, 19, 1269-1272. http://dx.doi.org/10.1016/j.arcped.2012.08.006

[19] Antona, D., Lévy-Bruhl, D., Baudon, C., Freymuth, F., Lamy, M., Maine, C., Floret, D. and Parent du Chatelet, I. (2013) Measles Elimination Efforts and 2008-2011 Outbreak, France. Emerging Infectious Diseases, 19, 357-364. http://dx.doi.org/10.3201/eid1903.121360

[20] Mayoral Cortes, J.M., Perez Morilla, E., Gallardo Garcia, V., Navarro Mari, J.M., Perez Ruiz, M., Hermosilla, R., Diaz-Borrego, J., Rodriguez Romero, E. and Ruiz Fernandez, J. (2012) Measles Outbreak in Andalusia, Spain, January to August 2011. Eurosurveillance, 17, pii=20300. http://www.eurosurveillance.org/ViewArticle.aspx?ArticleId=20300

[21] Lassen, S.G., Schuster, M., Stemmler, M., Steinmüller, A., Matysiak-Klose, D., Mankertz, A., Santibanez, S., Wichmann, O. and Falkenhorst, G. (2014) Measles Outbreak Spreading from the Community to an Anthroposophic School, Berlin, 2011. Epidemiology and Infection, 142, 789-796. http://dx.doi.org/10.1017/S0950268813001398

[22] Filia, A., Tavilla, A., Bella, A., Magurano, F., Ansaldi, F., Chironna, M., Nicoletti, L., Palu, G., Iannazzo, S., Declich, S. and Rota, M.C. (2011) Measles in Italy, July 2009 to September 2010. Eurosurveillance,16, pii=19925. http://www.eurosurveillance.org/ViewArticle.aspx?ArticleId=19925 
[23] Melidou, A., Gioula, G., Pogka, V., Exindari, M., Moutoussi, A., Sgouras, D., Papadakos, K., Chatzidimitriou, D., Karabaxoglou, D., Mentis, A. and Malisiovas, N. (2012) Molecular and Phylogenetic Analysis of Greek Measles 2010 Strains. Epidemiology and Infection, 140, 432-438. http://dx.doi.org/10.1017/S095026881100094X

[24] Schmid, D., Holzmann, H., Schwarz, K., Kasper, S., Kuo, H.W., Aberle, S.W., Redlberger-Fritz, M., Hautmann, W., Santibanez, S., Mankertz, A., König, C., Magnet, E., Reichart, S., Meusburger, S., Luckner-Hornischer, A., De Martin, A., Bechter, E., Stirling, J. and Allerberger, F. (2010) Measles Outbreak Linked to a Minority Group in Austria, 2008. Epidemiology and Infection, 138, 415-425. http://dx.doi.org/10.1017/S0950268809990604

[25] Castillo-Solorzano, C.C., Matus, C.R., Flannery, B., Marsigli, C., Tambini, G. and Andrus, K. (2011) The Americas: Paving the Road toward Global Measles Eradication. The Journal of Infectious Diseases, 204, S270-S278. http://dx.doi.org/10.1093/infdis/jir166

[26] De Serres, G., Markowski, F., Toth, E., Landry, M., Auger, D., Mercier, M., Bélanger, P., Turmel, B., Arruda, H., Boulianne, N., Ward, B.J. and Skowronski, D.M. (2013) Largest Measles Epidemic in North America in a DecadeQuebec, Canada, 2011: Contribution of Susceptibility, Serendipity, and Superspreading Events. The Journal of Infectious Diseases, 207, 990-998. http://dx.doi.org/10.1093/infdis/jis923

[27] Parker Fielbelkorn, A., Reed, S.B., Gallagher, K., Rota, P.A., Rota, J., Bellini, W. and Sewrd, J. (2010) Measles in the United States during the Postelimination Era. The Journal of Infectious Diseases, 202, 1520-1528. http://dx.doi.org/10.1086/656914

[28] Hill, M., Risk, I., Burnett, C., Garcia, W., Carter, A., Guerra, L., Goodsell, L., LaPriel, C., Redd, E., Nelson, S., Vernon, V., Leniek, K., Saw, L., Seward, J.F., Kutty, P.K., Wallace, G., Bellini, W.J., Rota, P.A., Rota, J. and Lanier, W.A. (2013) Two Measles Outbreaks After Importation-Utah, March-June 2011. Morbidity and Mortality Weekly Report, 62, 222-225.

[29] Outbreak of Measles in Wales Nov 2012-July 2013: Report of the Agencies Which Responded to the Outbreak. http://www.wales.nhs.uk/sitesplus/888/document/224574

[30] Shane, A., Hiebert, J., Sherrad, L. and Deehan, H. (2014) Measles Surveillance in Canada: Trends for 2013. Canada Communicable Disease Report CCDR, 40, 1-12.

[31] Wallace, G., Redd, S., Rota, J., Rota, P., Bellini, W. and Lebo, E. (2013) Measles-United States January 1-August 24, 2013. Morbidity and Mortality Weekly Report, 62, 741-743.

[32] Manual de Procedimientos Estandarizados para la vigilancia Epidemiológica de las Enfermedades Prevenibles por Vacunación. Secretaria de Salud, México, D.F. http://www.epidemiologia.salud.gob.mx/

[33] WHO (1996) Monitoring immunization services using the Lot Quality Technique. Global Programme for Vaccines and Immunization. Vaccine Research and Development. WHO/VRD/TRAM/96.01

[34] (2008) Consejo Nacional de Vacunación. Manual de Vacunación 2008-2009. Capítulo 4. Vacunas y toxoides. Secretaría de Salud, México.

[35] Hummel, K.B., Lowe, L., Bellini, W.J. and Rota, P.A. (2006) Development of Quantitative Gene-Specific Real-Time RT-PCR Assays for the Detection of Measles Virus in Clinical Specimens. Journal of Virological Methods, 132, 166173.

[36] WHO (2007) Manual for the Laboratory Diagnosis of Measles and Rubella Virus Infection, $2^{\text {nd }}$ edition. World Health Organization, Geneva.

[37] Dirección General de Epidemiología. Manual Caminando a la Excelencia Evaluación 2011-2012. Secretaría de Salud. México, D.F. http://www.epidemiologia.salud.gob.mx/

[38] Díaz-Ortega, J.L., Ferreira-Guerrero, E, Trejo-Valdivia, B., Téllez Rojo, M.M., Ferreyra-Reyes, L., Hernández-Serrato, M., Montoya-Rodríguez, A.A. and García-García, L. (2013) Cobertura de vacunación en niños y adolescentes en México: esquema completo, incompleto y no vacunación. Salud Pública de México, 55, S289-S299

[39] Jost, M., Luzi, D., Metzler, S., Miran, B., Mutsch, M. (2015) Measles Associated with International Travel in the Region of the Americas, Australia and Europe, 2001-2013: A Systematic Review. Travel Medicine and Infectious Disease, 13, 10-18. http://dx.doi.org/10.1016/j.tmaid.2014.10.022

[40] Lanini, S., Capobianchi, M.R., Puro, V., Filia, A., Del Manso, M., Kärki, T., Nicoletti, L., Magurano, F., Derrough, T., Severi, E., Bonfigli, S., Lauria, F.N., Ippolito, G., Vellucci, L., Pompa, M.G., and the Central Task Force for the Measles Outbreak (2014) Measles Outbreak on a Cruise Ship in the Western Mediterranean, February 2014, Preliminary Report. Eurosurveillance, 19, pii=20735. http://www.eurosurveillance.org/ViewArticle.aspx?ArticleId=20735 